\title{
Preparation and characterization of hydroxyapatite-coated iron oxide particles by spray-drying technique
}

\author{
KARINA DONADEL ${ }^{1}$, MARCOS D.V. FELISBERTO ${ }^{1}$ and MAURO C.M. LARANJEIRA ${ }^{1,2}$ \\ ${ }^{1}$ Programa de Pós-Graduação em Ciência e Engenharia de Materiais (PGMAT), Universidade Federal de Santa Catarina, \\ Campus Universitário, Trindade, Caixa Postal 476, 88040-900 Florianópolis, SC, Brasil \\ ${ }^{2}$ Departamento de Química, Grupo QUITECH, Universidade Federal de Santa Catarina, Campus Universitário, \\ Trindade, Caixa Postal 476, 88040-900 Florianópolis, SC, Brasil \\ Manuscript received on August 5, 2008; accepted for publication on February 5, 2009; \\ presented by FERNANDO GALEMBECK
}

\begin{abstract}
Magnetic particles of iron oxide have been increasingly used in medical diagnosis by magnetic resonance imaging and in cancer therapies involving targeted drug delivery and magnetic hyperthermia. In this study we report the preparation and characterization of iron oxide particles coated with bioceramic hydroxyapatite by spray-drying. The iron oxide magnetic particles (IOMP) were coated with hydroxyapatite (HAp) by spray-drying using two IOMP/HAp ratios ( 0.7 and 3.2$)$. The magnetic particles were characterized by way of scanning electronic microscopy, energy dispersive X-ray, X-ray diffraction, Fourier transformed infrared spectroscopy, flame atomic absorption spectrometry, vibrating sample magnetometry and particle size distribution (laser diffraction). The surface morphology of the coated samples is different from that of the iron oxide due to formation of hydroxyapatite coating. From an EDX analysis, it was verified that the surface of the coated magnetic particles is composed only of HAp, while the interior contains iron oxide and a few layers of HAp as expected. The results showed that spray-drying technique is an efficient and relatively inexpensive method for forming spherical particles with a core/shell structure.
\end{abstract}

Key words: iron oxide particles, hydroxyapatite, spray-drying.

\section{INTRODUCTION}

Iron oxide magnetic particles (IOMP) are of great interest for some biomedical applications, including therapeutic applications such as magnetic hyperthermia treatment of cancer, magnetic resonance imaging (MRI) and release of drugs.

The magnetic particles need to be pre-coated with substances that assure their stability, biodegradability, and non-physiological toxicity. Magnetic fluids are stable colloidal systems consisting of single-domain ferroferrimagnetic particles coated with a surfactant and dispersed in a carrier liquid. The biocompatible ferrofluids can be used as systems for anticancer agent released in

Correspondence to: Mauro C.M. Laranjeira

E-mail: mauro@qmc.ufsc.br the local region of the tumor and in magnetic hyperthermia treatment (Józefczak et al. 2005, Marin 2006, Wu et al. 2007).

Magnetic induction hyperthermia is a technique to destroy cancer cells by their hysteresis loss when placed under an alternating magnetic. The temperature of the cancerous tissue can be raised to within the range of 42$46^{\circ} \mathrm{C}$ by indirect heating produced by various magnetic materials, meanwhile normal cells are not damaged at even higher temperatures. Magnetic hyperthermia treatment generally is used in conjunction with other modalities of cancer treatment, with the objective of improving the effectiveness of the antineoplastic drugs (Alexiou et al. 2005, Neuberger et al. 2005, Park et al. 2005, Kawashita et al. 2005). 
Magnetic materials can be coated using biocompatible inorganic materials (Deb et al. 2003, Arcos et al. 2002, Ebisawa et al. 1997, Gross et al. 2002, Bretcanu et al. 2005) or polymers (Józefczak et al. 2005, Park et al. 2005, Gomez-Lopera et al. 2001, Donadel et al. 2008, Dutz et al. 2007, Okassa et al. 2005). Amongst the biocompatible materials used as coverings, bioceramic hydroxyapatite (HAp) has been used due to its known biocompatibility, non-toxicity and bioactivity. Calcium HAp, $\mathrm{Ca}_{10}\left(\mathrm{PO}_{4}\right)_{6}(\mathrm{OH})_{2}$, is the main inorganic component of hard bone tissues in vertebrates. It is a member of the apatite family of compounds, and accounts for $60-70 \%$ of the mineral phase in the human bone (Finisie et al. 2001, Kawachi et al. 2000, Murugan and Ramakrishna 2006, Donadel et al. 2005). The hydroxyapatite with magnetic properties can be used for the treatment of bone cancer by magnetic induction hyperthermia and to promote the bone formation (Gaihre et al. 2008).

Spray-drying is a technique that can be applied to prepare coating particles with relatively inexpensive cost. The spray-drying of an aqueous solution or suspension containing the particle to be coated is atomized into a warm chamber where the water is evaporated. It can be applied to prepare a surface-coated product.

The complete process consists basically of a sequence of four steps: atomization, mixing of spray and air, evaporation, and product separation (Makai et al. 2008, Luz et al. 2007, Freitas et al. 2004).

Here we report the use of HAp as a new coating for iron oxide particles to be applied in cancer treatment. These coated particles were characterized by scanning electronic microscopy (SEM), energy dispersive X-ray (EDX), X-ray diffraction (XRD), Fourier transformed infrared spectroscopy (FTIR), flame atomic absorption spectrometry (FAAS), vibrating sample magnetometry (VSM) and particle size distribution (laser diffraction).

\section{MATERIALS AND METHODS}

Iron oxide magnetic particles (magnetite) were prepared by alkaline co-precipitation of ferric and ferrous chlorides in aqueous solution. Solutions of $\mathrm{FeCl}_{3} \cdot 6 \mathrm{H}_{2} \mathrm{O}$ (0.25 mol.L $\left.\mathrm{L}^{-1}\right)$ and $\mathrm{FeCl}_{2} .4 \mathrm{H}_{2} \mathrm{O}\left(0.125 \mathrm{~mol} . \mathrm{L}^{-1}\right)$ were mixed and precipitated with $\mathrm{NaOH}$ solution $\left(1\right.$ mol.L $\left.\mathrm{L}^{-1}\right)$ at pH12, while stirring vigorously. The black suspen- sion, which formed immediately, was maintained at $70^{\circ} \mathrm{C}$ for approximately one hour and washed several times with ultra-pure water until the $\mathrm{pH}$ decreased to 7 (Kim et al. 2002).

A $0.16 \mathrm{~mol} / \mathrm{L}\left(\mathrm{NH}_{4}\right)_{2} \mathrm{HPO}_{4}$ solution was dripped into a stirred solution of $0.40 \mathrm{~mol} / \mathrm{L} \mathrm{Ca}\left(\mathrm{NO}_{3}\right)_{2} \mathrm{kept}$ at $60^{\circ} \mathrm{C}$. The $\mathrm{pH}$ was maintained at 10 with dilute $\mathrm{NH}_{4} \mathrm{OH}$ (28-30\%) solution. The mixture was then aged and vigorously stirred at its boiling point for around 2 hours. The HAp precipitates were filtered, washed with deionized water, and dried at $60^{\circ} \mathrm{C}$ (Finisie et al. 2001).

Samples with different iron oxide/hydroxyapatite ratios were prepared from the dropping of a solution of $\left(\mathrm{NH}_{4}\right)_{2} \mathrm{HPO}_{4}$ into a $\mathrm{Ca}\left(\mathrm{NO}_{3}\right)_{2}$ solution containing two different masses of the IOMP. The resulting suspension was kept at $60^{\circ} \mathrm{C}$ during the precipitation and the $\mathrm{pH}$ was maintained at 10 with the addition of $\mathrm{NH}_{4} \mathrm{OH}$. Two different ratios of magnetic particles to hydroxyapatite $(\mathrm{m} / \mathrm{m}), \mathrm{IOMP} / \mathrm{HAp}=0.7$ and IOMP/HAp $=3.2$, were obtained and the suspensions were atomized using the spray-drying technique.

The suspensions of uncoated and HAp-coated IOMP were atomized using a Büchi B-191 mini spraydrier (Flawil, Switzerland), with an atomizer nozzle orifice diameter of $0.7 \mathrm{~mm}$, and a chamber with $44 \mathrm{~cm}$ height and $10.5 \mathrm{~cm}$ inside diameter. The inlet and outlet air temperatures were 170 and $90^{\circ} \mathrm{C}$, respectively, with a positive pressure of 5 bar gauge. The aspirator was set at $95 \%$ capacity and compressed air flow at $600 \mathrm{NL} / \mathrm{h}$. The suspension feed rate (peristaltic pump setting) was $8 \mathrm{ml} / \mathrm{min}$.

The phases present in the magnetic materials were analyzed using a powder X-ray diffractometer (XRD) Philips (Holland), model $\mathrm{X}^{\prime}$ Pert with $\mathrm{CuK} \alpha 1$ radiation ( $\lambda=1.54056 \AA$ ), and the X-ray generator was operated at $40 \mathrm{KV}$ and $30 \mathrm{~mA}$.

The flame atomic absorption spectrometry (FAAS) technique was used to determine the amount of iron present in the samples. The measurements were performed in a Hitachi flame atomic absorption spectrometer, model Z8230.

Scanning electron microscope (SEM) (Philips XL30) with energy dispersive X-ray spectroscopy (EDX) was used for the morphological and microchemical analysis. The microchemical analysis was performed 
at 5 and $20 \mathrm{keV}$ in order to determine the chemical composition in the interior and at the surface of the particles.

Particle size distributions for coated and uncoated IOMP were determined using a laser diffraction particle size analyzer (Cilas, 1064L).

The magnetic properties were assessed with a vibrating sample magnetometer (VSM) LD, model 9600. The magnetic properties of the particles were evaluated in terms of saturation magnetization and coercivity.

\section{RESULTS AND DISCUSSION}

Figures 1 (a-d) showed XRD of the IOPM, HAp and coated samples. The Figure 1a, XRD results showed that the IOMP were a mixture of two oxides. According to the JCPDS cards (ICDD and JCPDS 1981), the peaks displayed on the diffratogram are characteristics of magnetite $\left(\mathrm{Fe}_{3} \mathrm{O}_{4}\right)$ (JCPDS 19-0629) and maghemite $\left(\gamma-\mathrm{Fe}_{2} \mathrm{O}_{3}\right)$ (JCPDS 39-1346). These two phases are very similar in terms of their crystalline structure, cubic spinal-type, and physical properties. Since the synthesis was carried out in air and at a high drying temperature $\left(170^{\circ} \mathrm{C}\right)$, a partial oxidation of the magnetite to maghemite occurred as shown in reactions 1 and 2 (Balasubramaniam et al. 2004, Chen et al. 2005, Da Costa et al. 1994):

$$
\begin{gathered}
\mathrm{FeCl}_{2}+2 \mathrm{FeCl}_{3}+8 \mathrm{NH}_{4} \mathrm{OH} \\
\rightarrow \mathrm{Fe}_{3} \mathrm{O}_{4}+8 \mathrm{NH}_{4} \mathrm{Cl}+4 \mathrm{H}_{2} \mathrm{O} \\
4 \mathrm{Fe}_{3} \mathrm{O}_{4}+\mathrm{O}_{2} \rightarrow 6 \gamma-\mathrm{Fe}_{2} \mathrm{O}_{3} .
\end{gathered}
$$

Figure $1 \mathrm{~b}$ shows the X-ray pattern obtained for the HAp. Through the analysis of the diffratogram it was observed that the HAp is the only crystalline phase present in the sample according to the JCPDS (9-432) cards. There was no indication of the presence of the phases $\beta$-TCP (JCPDS 9-169) and CaO (JCPDS 4-777), which can be formed during the synthesis (Murugan and Ramakrishna 2006, Donadel et al. 2005). Figures 1c and $1 \mathrm{~d}$ show the X-ray pattern obtained for IOMP/HAp $=0.7$ and IOMP/HAp $=3.2$, respectively. The XRD patterns of the coated samples could be attributed to the phases hydroxyapatite and iron oxide (magnetite/ maghemite) as the only phases which indicate coating of hydroxyapatite on the particles surface.

On the contrary, if an iron ions substitution into hydroxyapatite structure occurred, a change in the XRD

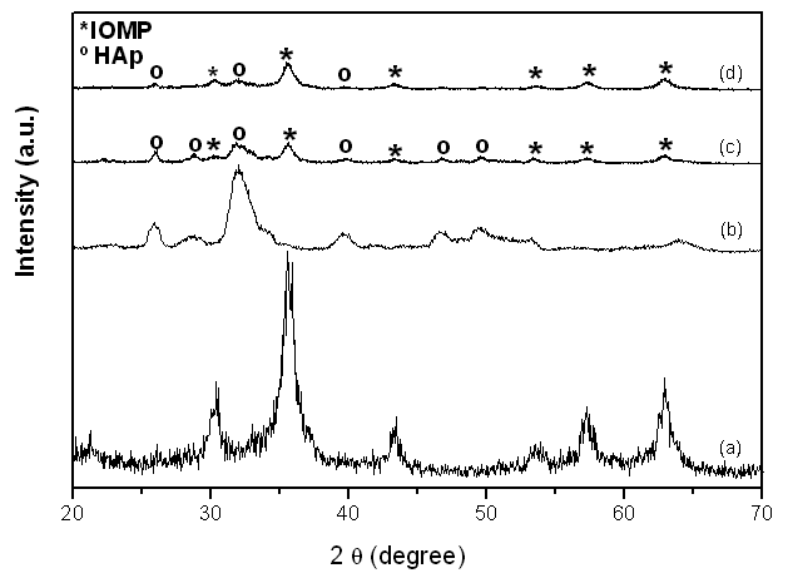

Fig. 1 - The X-ray diffraction powder patterns: (a) IOMP; (b) HAp; (c) IOPM/HAp $=0.7$ and (d) IOPM/HAp $=3.2$.

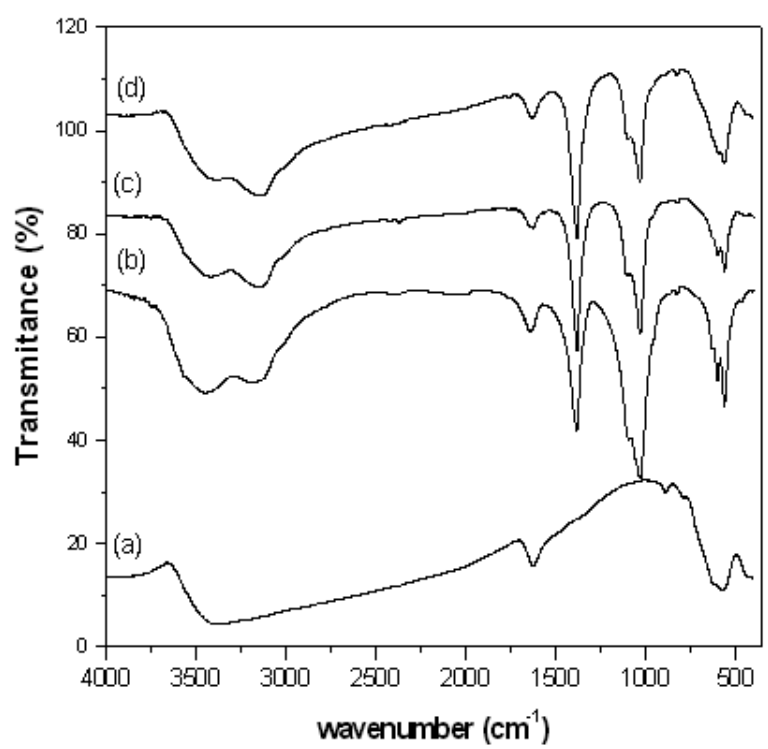

Fig. 2 - Infrared absorption spectra: (a) IOMP; (b) HAp; (c) IOPM/ $\mathrm{HAp}=0.7$ and (d) IOPM/HAp $=3.2$.

patterns with formation of a new phase, which contains iron, will be observed (Pon-On et al. 2007).

Figure 2 shows a comparison among the Fourier transform infrared spectra on (a) uncoated IOMP, (b) HAp, and (c and d) HAp-coated IOMP. The absorption bands of the IOMP which appeared at 575 and $580 \mathrm{~cm}^{-1}$ are assigned to Fe-O deformation at the octahedral and tetrahedral sites. The $\mathrm{OH}$ stretching and $\mathrm{HOH}$ bending vibrational bands at $3380 \mathrm{~cm}^{-1}$ and $1630 \mathrm{~cm}^{-1}$, respectively, are due to the adsorbed water in the sample 
(Fig. 2a). The HAp spectrum had an absorption band at $1032 \mathrm{~cm}^{-1}$, which is related to the stretching vibrations of the phosphate group $\mathrm{PO}_{4}^{3-}$, and the bands at 603 and $565 \mathrm{~cm}^{-1}$ are related to the deformation vibrations of the $\mathrm{PO}_{4}^{3-}$ group. The $\mathrm{OH}$ stretching bands that appear at $3576 \mathrm{~cm}^{-1}$ are covered by the broad band $3447 \mathrm{~cm}^{-1}$ of $\mathrm{H}_{2} \mathrm{O}$ molecules, which may be freed or adsorbed (Finisie et al. 2001, Murugan and Ramakrishna 2006, Donadel et al. 2005). The band at $1388 \mathrm{~cm}^{-1}$ is related to the $\mathrm{N}-\mathrm{O}$ stretching of the $\mathrm{NO}_{3}-$ group and the band at $3180 \mathrm{~cm}^{-1}$ can be attributed to $\mathrm{N}-\mathrm{H}$ stretching of the $\mathrm{NH}_{4}$ group (Anee et al. 2003). These bands may precede the formation of the by-product $\mathrm{NH}_{4} \mathrm{NO}_{3}$ during the synthesis of HAp, as shown in reaction (3) (Fig. 2b).

$$
\begin{aligned}
10 \mathrm{Ca}\left(\mathrm{NO}_{3}\right)_{2}+6\left(\mathrm{NH}_{4}\right)_{2} \mathrm{HPO}_{4}+8 \mathrm{NH}_{4} \mathrm{OH} \\
\rightarrow \mathrm{Ca}_{10}\left(\mathrm{PO}_{4}\right)_{6}(\mathrm{OH})_{2}+20 \mathrm{NH}_{4} \mathrm{NO}_{3}+6 \mathrm{H}_{2} \mathrm{O}
\end{aligned}
$$

The spectra of the coated particles (Figs. 2c and 2d) exhibit characteristic absorption bands of the functional groups of HAp, while the peaks of the iron oxide particles did not appear since the bands at 575 and $580 \mathrm{~cm}^{-1}$ are probably hidden by the peaks of the HAp.

Since it is difficult to differentiate between maghemite and magnetite by XRD because the two minerals have similar crystal structures (Rivers et al. 2004), the technique of FAAS was used to determine the amount of iron present in the samples and, from this analysis, the ratio of magnetite to maghemite in the synthesized IOMP was calculated. The ratio found for the IOMP was $55.0 \%$ of magnetite $\left(\mathrm{Fe}_{3} \mathrm{O}_{4}\right)$ and $45.0 \%$ of maghemite $\left(\mathrm{Fe}_{2} \mathrm{O}_{3}\right)$. The experimental IOMP/coating ratios were determined considering this magnetite/maghemite ratio. Equations 4 and 5 were used to calculate the ratios:

$$
\begin{gathered}
2 \mathrm{n}\left(\mathrm{Fe}_{2} \mathrm{O}_{3}\right) \cdot \mathrm{M}(\mathrm{Fe})+3 \mathrm{n}\left(\mathrm{Fe}_{3} \mathrm{O}_{4}\right) \cdot \mathrm{M}(\mathrm{Fe})=41.6 \mathrm{mg} \\
\mathrm{n}\left(\mathrm{Fe}_{2} \mathrm{O}_{3}\right) \cdot \mathrm{M}\left(\mathrm{Fe}_{2} \mathrm{O}_{3}\right)+\mathrm{n}\left(\mathrm{Fe}_{3} \mathrm{O}_{4}\right) \cdot \mathrm{M}\left(\mathrm{Fe}_{3} \mathrm{O}_{4}\right)=50.0 \mathrm{mg}
\end{gathered}
$$

where " $\mathrm{n}$ " is number of mols and " $\mathrm{M}$ "' is molecular weight.

Table I gives the results obtained from the FAAS analysis for the determination of IOMP/coating ratios.

Morphological studies were also carried out and are shown in Figures 3 and 4. Figure 3 shows the morphology of the IOMP surface before (Fig. 3a) and after (Fig. 3b) the spray-drying process. It can be observed that, after the spray-drying, the particles acquired a spherical form. This is due to the evaporative cooling effect when the spherical spray droplets are dried in the heated chamber of the spray-dryer apparatus forming spherical particles (Donadel et al. 2008).

Spray drying can also be used as an encapsulation method when it entraps a material within a polymeric or ceramic protective shell that is essentially inert to the material being encapsulated (Luz et al. 2007).

Figure 4(a-b) shows the electron micrographs of HAp-coated samples. It can be observed that these samples are smaller than uncoated particles (Fig. 3b) and are in an agglomerated form. Surface morphology of the coated samples is different from that of the iron oxide as would be expected due to formation of hydroxyapatite coating (Deb et al. 2003).

EDX analysis using acceleration voltages set at $5 \mathrm{keV}$ and $20 \mathrm{keV}$ was performed to determine the chemical composition of the elements present from the surface to the interior of the particles. This analysis also confirmed our observations on coating verified by SEM analysis above reported.

As the beam voltage is reduced $(5 \mathrm{keV})$, the electrons excite X-rays to lesser depths, which enable the characterization of the surface elemental composition of particles. However, by using the electron beam at $20 \mathrm{keV}$ an EDX analysis of the composition of the interior particle was determined, at a depth of 1.2 micrometers. Table II shows the results obtained from the EDX analysis at $5 \mathrm{keV}$ and $20 \mathrm{keV}$ for the HAp-coated samples. The concentrations of carbon and oxygen are much higher on the surface (electron beam at $5 \mathrm{keV}$ ) than in the interior of coated particles (electron beam at $20 \mathrm{keV}$ ), while the iron appears only in the analysis performed at $20 \mathrm{keV}$. Thus, based on the EDX analysis, it was verified that the surface of the coated magnetic particles is composed only of HAp, while the interior contains iron oxide and a few layers of HAp as expected. A similar characterization of HAp-coated ferrite particles using EDX with electron beam acceleration voltages of 20 and $5 \mathrm{keV}$ was carried out by Deb et al. (2003). The authors verified that iron was essentially absent on the surface, whereas in the core its concentration was very high, as would be expected.

The size distribution of the coated and uncoated 
TABLE I

Flame atomic absorption spectrometry results from uncoated and coated iron oxide magnetic particles.

\begin{tabular}{c|c|c|c|c}
\hline \multirow{2}{*}{ Samples } & \multicolumn{2}{|c|}{ Mass $(\mathrm{mg}) \pm \mathrm{sd}$} & \multicolumn{2}{c}{ Ratios $(\mathrm{m} / \mathrm{m}) \pm \mathrm{sd}$} \\
\cline { 2 - 5 } & Iron & Iron oxides & \multicolumn{2}{|c}{} \\
\hline IOMP $^{\mathrm{a}}$ & $41.6 \pm 2.14$ & $50.0^{*}$ & & \\
\hline $\mathrm{IOMP}_{\mathrm{HAAp}}^{\mathrm{b}}=0.7$ & $41.8 \pm 1.08$ & $58.6 \pm 2.59$ & 0.5 & $0.7 \pm 0.07$ \\
\hline IOMPF/HAp $=3.2$ & $40.7 \pm 1.92$ & $57.1 \pm 3.11$ & 2.0 & $3.2 \pm 0.82$ \\
\hline
\end{tabular}

*Weighed mass; ${ }^{\text {a } i r o n ~ o x i d e ~ m a g n e t i c ~ p a r t i c l e s ; ~}{ }^{b}$ hydroxyapatite.
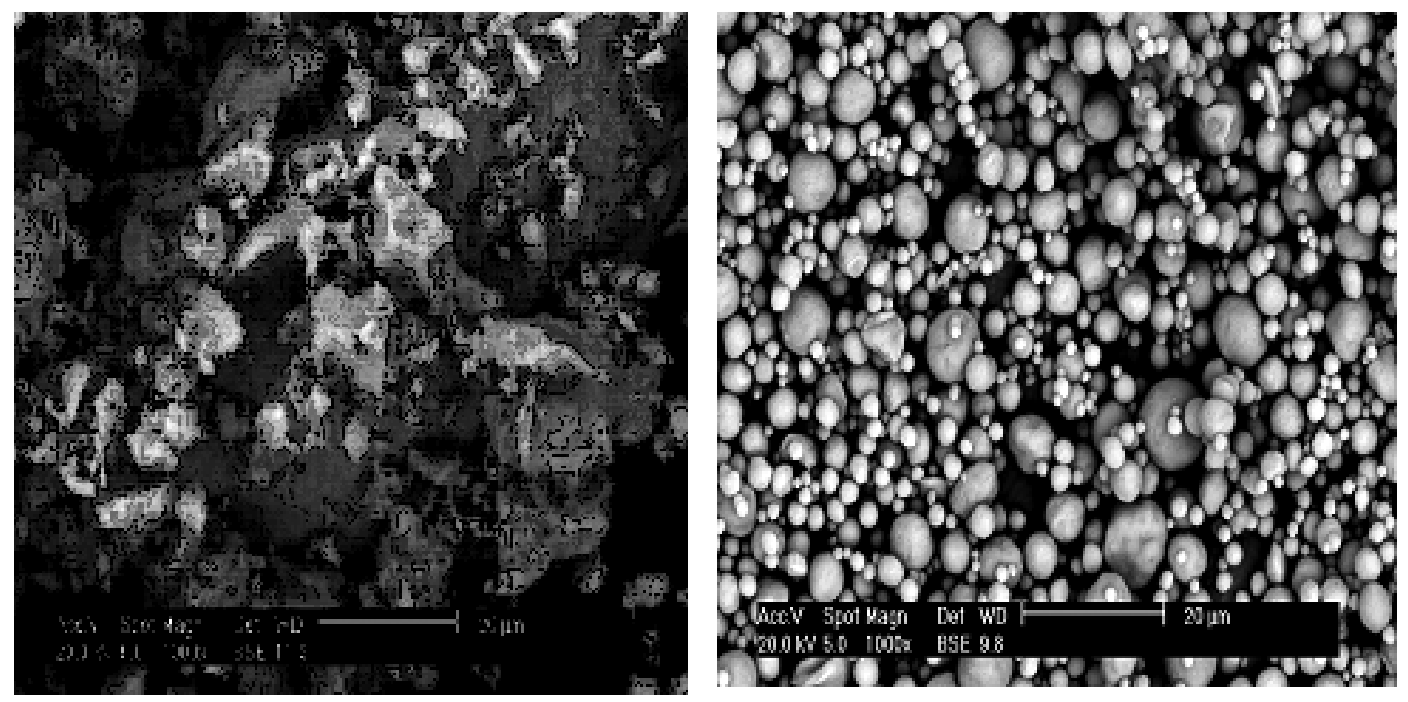

Fig. 3 - Scanning electronic microscopy micrographs of: (a) iron oxide magnetic particles before spray-drying and (b) iron oxide magnetic particles after spray-drying.
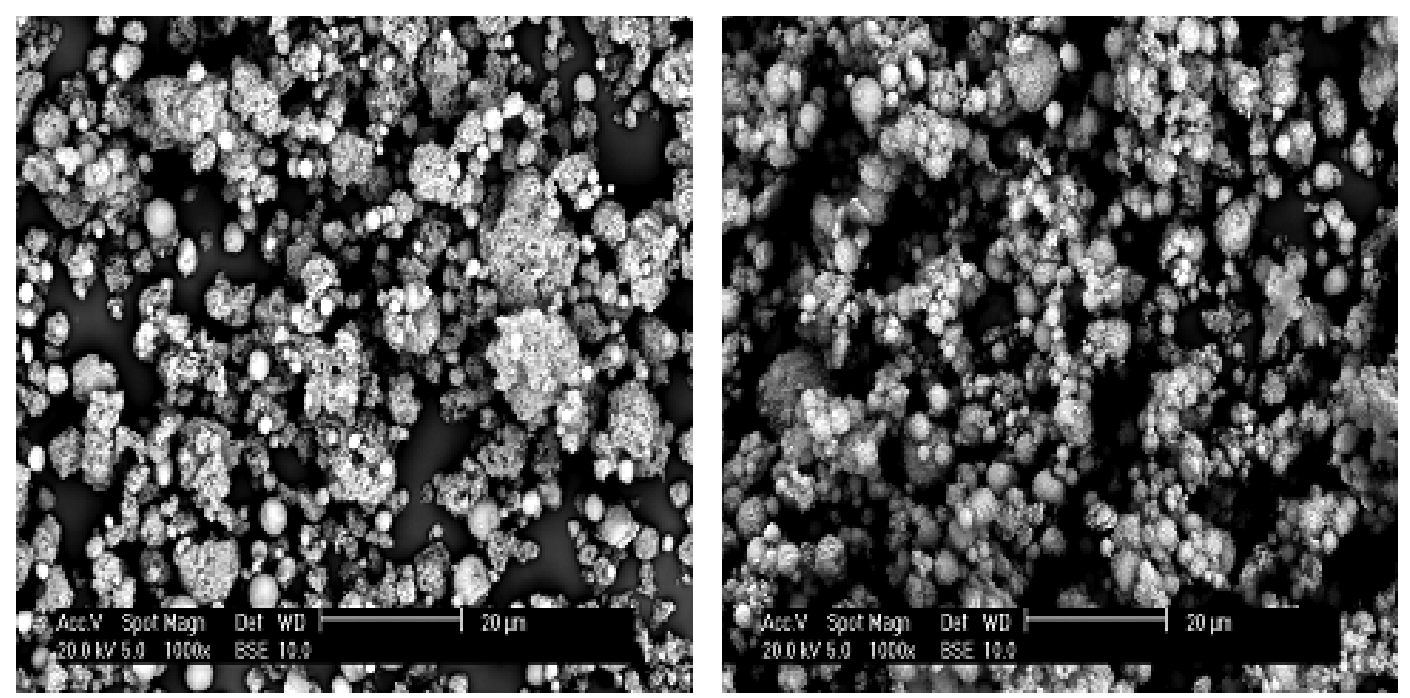

Fig. 4 - Scanning electronic microscopy micrographs of: (a) IOMP/HAp $=0.7$ and (b) IOMP/HAp $=3.2$. 
TABLE II

EDX analyses of hydroxyapatite-coated iron oxide magnetic particles display the comparative variation of elemental composition of the interior (with $20 \mathrm{keV}$ ) and the surface (with $5 \mathrm{keV}$ ).

\begin{tabular}{cl|c|c}
\hline Samples & $\begin{array}{c}\text { Atomic } \\
\text { weight } \\
\%(5 \mathrm{keV})\end{array}$ & $\begin{array}{c}\text { Atomic } \\
\text { weight } \\
\%(20 \mathrm{keV})\end{array}$ \\
\hline IOMP/HAp $=0.7$ & $\mathrm{O}$ & 21.17 & 31.80 \\
& $\mathrm{P}$ & 23.11 & 15.26 \\
& $\mathrm{Ca}$ & 55.73 & 26.31 \\
& $\mathrm{Fe}$ & - & 26.63 \\
\hline IOMP/HAp $=3.2$ & $\mathrm{O}$ & 23.49 & 21.35 \\
& $\mathrm{P}$ & 20.65 & 7.96 \\
& $\mathrm{Ca}$ & 55.85 & 13.36 \\
& $\mathrm{Fe}$ & - & 57.32 \\
\hline
\end{tabular}

IOMP was investigated by laser diffraction particle size analysis. The analysis revealed that $100 \%$ of the uncoated particles were found to be below $36.00 \mu \mathrm{m}$, and $90 \%, 50 \%$ and $10 \%$ of the particles were smaller than $13.92 \mu \mathrm{m}, 2.47 \mu \mathrm{m}$ and $0.53 \mu \mathrm{m}$, respectively. The particles size distribution for both coated samples IOMP/ HAp $=0.7$ and IOMPF/HAp $=3.2$ were very close, falling in the size range of 0.47 to $12 \mu \mathrm{m}$. The coated and uncoated samples reveled a non-uniformity in the particle size distribution.

Figures 5 and 6 show the magnetization curves for uncoated and HAp-coated IOMP, respectively. The magnetization curve of IOMP in Figure 5 gives a saturation magnetization value of $33 \mathrm{emu} / \mathrm{g}$. This value is lower than the values reported in the literature (51-67 emu/g) since the IOMP material is a mixture of two oxides, magnetite (55.0\%) and maghemite (45.0\%) (Kim et al. 2005, Lian et al. 2004).

When the IOMP/HAp ratio decreases, the saturation magnetization values also decrease (Table III). The magnetization values for the coated samples were lower than those for the iron oxide particles $\left(\mathrm{Fe}_{3} \mathrm{O}_{4} / \gamma-\mathrm{Fe}_{2} \mathrm{O}_{3}\right)$. The decreased saturation magnetization should be attributed to the interaction between the iron core with the hydroxyapatite shell, which reduced the total magnetic moments (Ramanujan and Yeow 2005, Cheng et al. 2006). This value is related to the amount of HAp that coats the iron oxide particles.

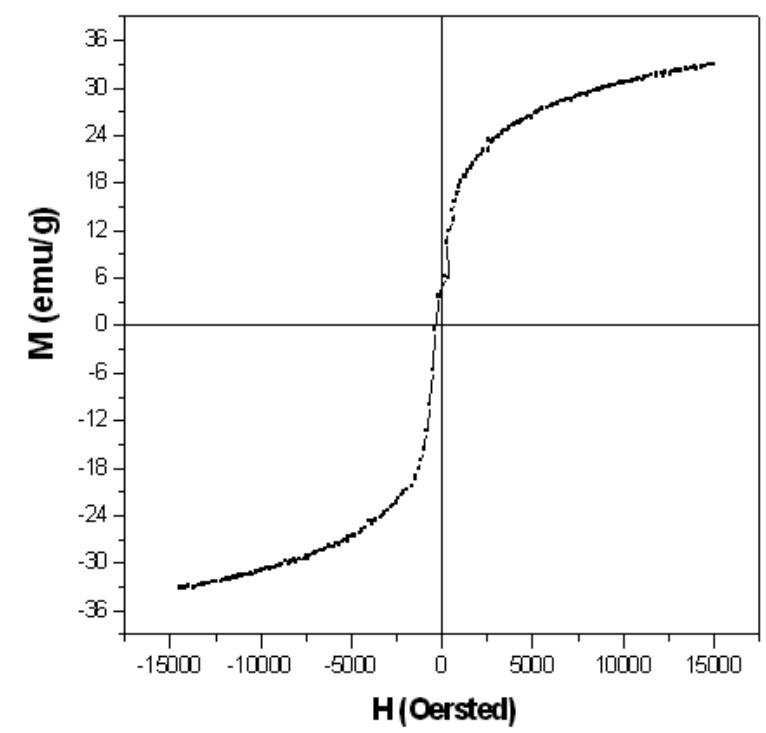

Fig. 5 - Magnetization curve of iron oxide magnetic particles.

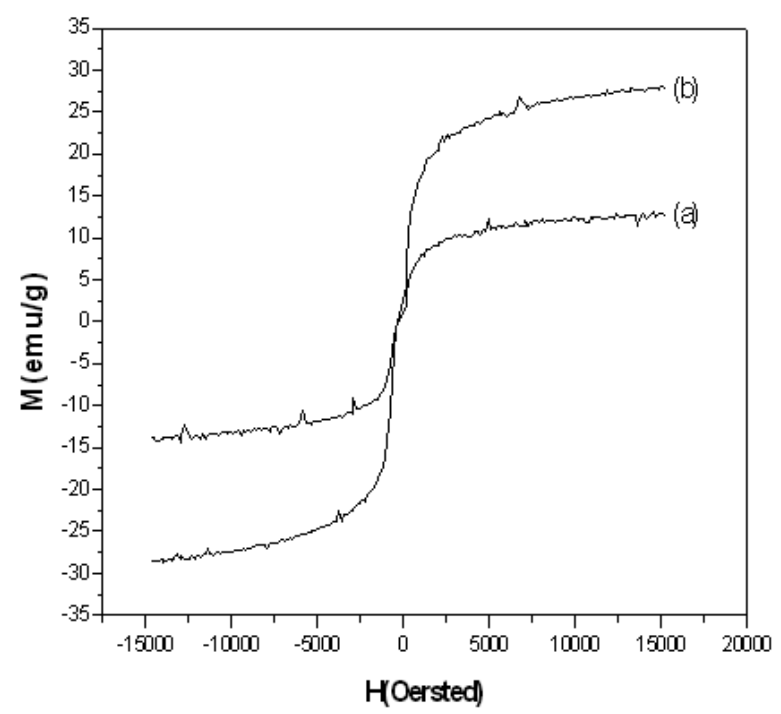

Fig. 6 - Magnetization curves of the samples coated with hydroxyapatite: (a) IOMP/HAp $=0.7$; and (b) IOMP/HAp $=3.2$.

\section{ACKNOWLEDGMENTS}

We thank Coordenação de Aperfeiçomento de Pessoal de Nível Superior (CAPES) for a maintenance grant (to K.D.) and Conselho Nacional de Desenvolvimento Científico e Tecnológico (CNPq) for financial support.

\section{RESUMO}

As partículas de óxido de ferro têm sido extensivamente usadas em diagnósticos médicos como agente de contraste para 
TABLE III

Magnetic properties of iron oxide particles and hydroxyapatite coated samples.

\begin{tabular}{c|c|c|c}
\hline Samples & $\begin{array}{c}\text { Saturation magnet- } \\
\text { ization }(\mathrm{emu} / \mathrm{g})\end{array}$ & $\begin{array}{c}\text { Magnetic material } \\
\text { in the samples }(\%)\end{array}$ & $\begin{array}{c}\text { Coercivity } \\
(\mathrm{Oe})\end{array}$ \\
\hline $\mathrm{IOMP}\left(\mathrm{Fe}_{3} \mathrm{O}_{4} / \gamma-\mathrm{Fe}_{2} \mathrm{O}_{3}\right)$ & 33.0 & 100 & 330 \\
$\mathrm{IOMP} / \mathrm{HAp}=0.7$ & 12.8 & 34.2 & 307 \\
$\mathrm{IOMP} / \mathrm{HAp}=3.2$ & 27.6 & 65.0 & 320 \\
\hline
\end{tabular}

imagem por ressonância magnética e na terapia do câncer, dentre estas, liberação de fármacos em sitos alvos e hipertermia magnética. Neste estudo nós reportamos a preparação e caracterização de partículas magnéticas de óxido de ferro revestidas com a biocerâmica hidroxiapatita. As partículas magnéticas de óxido de ferro (PMOF) foram revestidas com hidroxiapatita por spray-drying usando duas razões PMOF/HAp $(0,7$ e 3,2). As partículas magnéticas foram caracterizadas por microscopia eletrônica de varredura, energia dispersiva de raios $\mathrm{X}$, difração de raios X, espectroscopia de absorção no infravermelho com transformada de Fourier, espectrometria de absorção atômica com atomização em chama, magnetometria de amostra vibrante e distribuição do tamanho de partícula (difração a laser). A morfologia da superfície das amostras revestidas é diferente das de óxido de ferro devido à formação do revestimento de hidroxiapatita. A partir da análise de energia dispersiva de raios $\mathrm{X}$ foi verificado que a superfície das partículas magnéticas é composta somente por hidroxiapatita, enquanto o interior contém óxido de ferro e uma pequena camada de hidroxiapatita, como esperado. Os resultados mostraram que a técnica de spray-drying é um método eficiente e relativamente de baixo custo para formação de partículas esféricas com estrutura núcleo/casca.

Palavras-chave: partículas de óxido de ferro, hidroxiapatita, spray-drying.

\section{REFERENCES}

Alexiou C, Jurgons R, Schmid R, Hilpert A, BergeMANN C, PARAK F AND IRO H. 2005. In vitro and in vivo investigations of targeted chemotherapy with magnetic nanoparticles. J Magn Magn Mater 293: 389-393.

Anee TK, Ashok M, Palanichamy M and Kalkura SN. 2003. A Novel Technique to Synthesize Hydroxyapatite at Low Temperature. Mater Chem Phys 80: 725-730.

Arcos D, Real RP ANd Vallet-Regi M. 2002. A novel bioactive and magnetic biphasic material. Biomaterials 23: $2151-2158$.
Balasubramaniam C, Khollam YB, Bannerjee I, BAKARE PP, DATE SK, DAS AK AND BHORASKAR SV. 2004. DC thermal arc-plasma preparation of nanometric and stoichiometric spherical magnetite $\left(\mathrm{Fe}_{3} \mathrm{O}_{4}\right)$ powders. Mater Lett 58: 3958-3962.

Bretcanu O, Spriano S, Verné E, Côisson M, Tiberto P AND Allia P. 2005. The influence of crystallised $\mathrm{Fe}_{3} \mathrm{O}_{4}$ on the magnetic properties of coprecipitation-derived ferrimagnetic glass-ceramics. Acta Biomater 1: 421-429.

Chen T, Xu H, Xie Q, Chen J, Ji J And Lu H. 2005. Characteristics and genesis of maghemite in Chinese loess and paleosols: Mechanism for magnetic susceptibility enhancement in paleosols. Earth and Planet Sci Lett 240: 790-802.

Cheng J, Ni X, Zheng H, Li B, Zhang X AND Zhan D. 2006. Preparation of $\mathrm{Fe}$ (core)/ $/ \mathrm{SiO}_{2}$ (shell) composite particles with improved oxidation-resistance. Mater Res Bull 41: 1424-1429.

DA Costa GM, DE Grave E, DE BAKKer PMA AND VANDENBERGHE RE. 1994. Synthesis and Characterization of Some Iron Oxides by Sol-Gel Method. J Solid State Chem 113: 405-412.

Deb S, Giri J, Dasgupta S, Datta D and Bahadur D. 2003. Synthesis and characterization of biocompatible hydroxyapatite coated ferrite. Bull Mater Sci 26: 655-660.

DONADEL K, LARANJEIRA MCM, FAVERE VT, GONÇALVES VL, Lima JC AND PRATES LHM. 2005. Hydroxyapatites Produced by Wet-Chemical Methods. J Am Ceram Soc 88: 2230-2235.

Donadel K, Felisberto MD, FaVere VT, Rigoni M, BAtistela NJ AND LARANJEIRA MCM. 2008. Synthesis and characterization of the iron oxide magnetic particles coated with chitosan biopolymer. Mat Sci Eng C 28: 509-514.

Dutz S, Andra W, Hergt R, Müller R, Oestreich C, SCHMidT C, TÖpfER J, Zeisberger M ANd BELleMANN ME. 2007. Influence of dextran coating on the 
magnetic behaviour of iron oxide nanoparticles. J Magn Magn Mater 311: 51-54.

Ebisawa Y, MiYaji F, KoKUbo T, OHURA K AND NAKAMURA T. 1997. Bioactivity of ferrimagnetic glass-ceramics in the system $\mathrm{FeO}-\mathrm{Fe}_{2} \mathrm{O}_{3}-\mathrm{CaO}-\mathrm{SiO}_{2}$. Biomaterials 18: $1277-1284$.

Finisie MR, Josue A, FAVERE VT AND LARANJEIRA MCM. 2001. Synthesis of Calcium-Phosphate and Chitosan Bioceramics for Bone Regeneration. An Acad Bras Cienc 73: 525-532.

Freitas S, MERKLE HP AND GANDER B. 2004. Ultrasonic atomisation into reduced pressure atmosphere-envisaging aseptic spray-drying for microencapsulation. J Control Release 95: 185-195.

Gaihre B, Aryal S, Barakat NAM AND Kim HY. 2008 Gelatin stabilized iron oxide nanoparticles as a three dimensional template for the hydroxyapatite crystal nucleation and growth. Mater Sci Eng C 28: 1297-1303.

Gomez-Lopera SA, Plaza RC And Delgado AV. 2001. Synthesis and Characterization of Spherical magnetite/ Biodegradable Polymer Composite Particles. Colloid Interf Sci 240: 40-47.

Gross KA, JACKSON R, CASHION JD AND RODRIGUEZLORENZO LM. 2002. Iron substituted apatites: a resorbable biomaterial with potential magnetic properties. Eur Cells Mater 3: 114-117.

ICDD (International Center for Diffraction Data) AND JCPDS (Joint Committee of Powder Diffraction Standards). 1981. Pennsylvania, USA.

JózefCZAK A, SKUMIEL A AND LABOWSKi M. 2005. Effects of biocompatible coating of nanoparticles on acoustics property of the magnetic fluid. J Magn Magn Mater 290-291: 265-268.

KaWachi EY, Betran C, Reis RR and Alves OL. 2000. Biocerâmicas: Tendências e Perspectivas de uma Área Interdiciplinar. Quim Nova 23: 518-522.

Kawashita M, Tanaka M, Kokubo T, Inoue Y, YaO T, HAMAda S And Shinjo T. 2005. Preparation of ferrimagnetic magnetite microspheres for in situ hyperthermic treatment of cancer. Biomaterials 26: 2231-2238.

Kim YS, Nakatsuka K, Fujita T And Atarashi T. 2002. US Pat 6: 440-322.

Kim EH, Lee HS, KwaK BK And Kim BK. 2005. Synthesis of ferrofluid with magnetic nanoparticles by sonochemical method for MRI contrast agent. J Magn Magn Mater 289: 328-330.
Lian S, WANG E, Kang Z, Bai Y, GaO L, JiAnG M, HU C AND XU L. 2004. Synthesis of magnetite nanorods and porous hematite nanorods. Solid State Commun 129: 485-490.

Luz PP, Pires AM And Serra AO. 2007. A low-cost ultrasonic spray dryer to produce spherical microparticles from polymeric matrices. Quim Nova 30: 1744-1746.

Makai Z, Bajdik J, ERos I ANd PintYe-Hódi K. 2008. Evaluation of the effects of lactose on the surface properties of alginate coated trandolapril particles prepared by a spray-drying method. Carbohydr Polym 74: 712-716.

MARIN CN. 2006. Thermal and particle size distribution effects on the ferromagnetic resonance in magnetic fluids. J Magn Magn Mater 300: 397-406.

Murugan R AND RAMAKRIShna S. 2006. Production of ultra-fine bioresorbable carbonated hydroxyapatite. Acta Biomaterialia 2: 201-206.

Neuberger T, Schöpf B, Hofmann H, Hofmann M AND VON RECHENBERG B. 2005. Superparamagnetic nanoparticles for biomedical applications: Possibilities and limitations of a new drug delivery system. J Magn Magn Mater 293: 483-496.

Okassa LN, Marchais H, Douziech-Eyrolles L, Cohen-Jonathan S, Soucé M, Dubois P And ChourPa I. 2005. Development and characterization of sub-micron poly(d,l-lactide-co-glycolide) particles loaded with magnetite/maghemite nanoparticles. Int J Pharm 302: 187-196.

PARK JH, IM KH, LEE SH, Kim DH, LEE DY, LEE YK, KIM KM AND KIM KN. 2005. Preparation and characterization of magnetic chitosan particles for hyperthermia application J Magn Magn Mater 293: 328-333.

PON-ON W, MEEJOO S AND TANG IM. 2007. Incorporation of iron into nano hydroxyapatite particles synthesized by the microwave process. Inter J Nanosci 6: 9-16.

RAMANUJAN RV AND YEOW YY. 2005. Synthesis and characterisation of polymer-coated metallic magnetic materials. Mater Sci Eng C 25: 39-41.

RIVERs JM, NyQuist JE, ROH Y, TERRY JR DO AND DOLL WE. 2004. Investigation into the Origin of Magnetic Soils on the Oak Ridge Reservation, Tennessee. Soil Sci Soc Am J 68: 1772-1779.

Wu HS, WANG TW, SUN JS, WANG WH AND LIN FH. 2007. A novel biomagnetic nanoparticle based on hydroxyapatite. Nanotechnology 18: 1-9. 